\title{
Elliot Lake, Ontario uranium mines a legacy perpetual care case study
}

\author{
DS Berthelot BHP, Canada \\ D Place-Hoskie $B H P$, USA \\ D Willems $B H P, U S A$ \\ K Black BHP, USA
}

\begin{abstract}
Twelve uranium mines were opened in the vicinity of Elliot Lake, Ontario Canada between 1955 and 1958. In the early 1960s, eight of these mines were acquired and amalgamated to form Rio Algom Limited (RAL), now a subsidiary of BHP. During the 1960s only two mines were operational with remaining mines placed in care and maintenance. Two mines were reactivated and one expanded in the late 1970 s and subsequently closed between 1990 and 1996. This construction and operating history produced eight tailings management areas with $102 \mathrm{Mt}$ of tailings (range of 0.08 to $46 \mathrm{Mt}$ ), covering 920 ha (range of 13 ha to $400 \mathrm{ha}$ ) and various cover configurations (water, vegetated and combinations thereof). As part of the federal environmental assessment review process for closure, all facilities were subject to cost-benefit analysis to select final closure configuration. Closure was implemented at all facilities between 1992 and 2000 to meet then best practice for nuclear waste facilities. This paper will provide a 20-year post-closure perspective of water management, water treatment and watershed performance and key learnings for these perpetual care facilities.
\end{abstract}

Keywords: closure, perpetual care, legacy sites, water management, water treatment

\section{Introduction}

Twelve underground uranium mines and eleven mills were opened in the vicinity of Elliot Lake, Ontario Canada between 1955 and 1958 (Figure 1). In 1954 the Ontario government decided to plan and establish Elliot Lake to serve the mining industry and by 1957 the community's population had grown to 27,000. In 1959 the US Atomic Energy Commission announced that contracts would not be extended beyond 1963, resulting in closure of seven of the then remaining nine mines. Two mines remained operational under a federal stockpiling program (Nordic and Denison) and one mill, Pronto, was repurposed for copper production from the Pater Mine. Rio Algom Limited (RAL), now a subsidiary of BHP, was formed during this time through the amalgamation of seven of the closed facilities plus the Nordic and Pronto/Pater operating properties (Table 1).

Growth in the nuclear power industry in the early 1970s led RAL and the other operator in the watershed, Denison Mines Limited, to plan increased production at their Elliot Lake facilities. The planned expansion triggered a joint environmental assessment including public hearings before a provincial Environmental Assessment Review Board between 1976 and 1979. Expansion of the Quirke facility and reactivation of Panel by RAL started in 1979 followed by reactivation of the Stanleigh facility in 1983.

Cancellation of the long-term supply contracts with Ontario Hydro led to the closure of the Quirke and Panel facilities in 1990 followed by the Denison facilities in 1992. Decommissioning of the tailings facilities was subject to environmental assessment (RAL 1995) with federal public hearings (Canadian Environmental Assessment Agency (CEAA) 1996). The Stanleigh facility continued to operate until June of 1996 as part of the community transition and stabilisation plan and was subject to Comprehensive Study Report environmental assessment (RAL 1997). Environmental assessment and federal review of the non-operated legacy sites was completed in 2002 by the Canadian Nuclear Safety Commission (CNSC). 


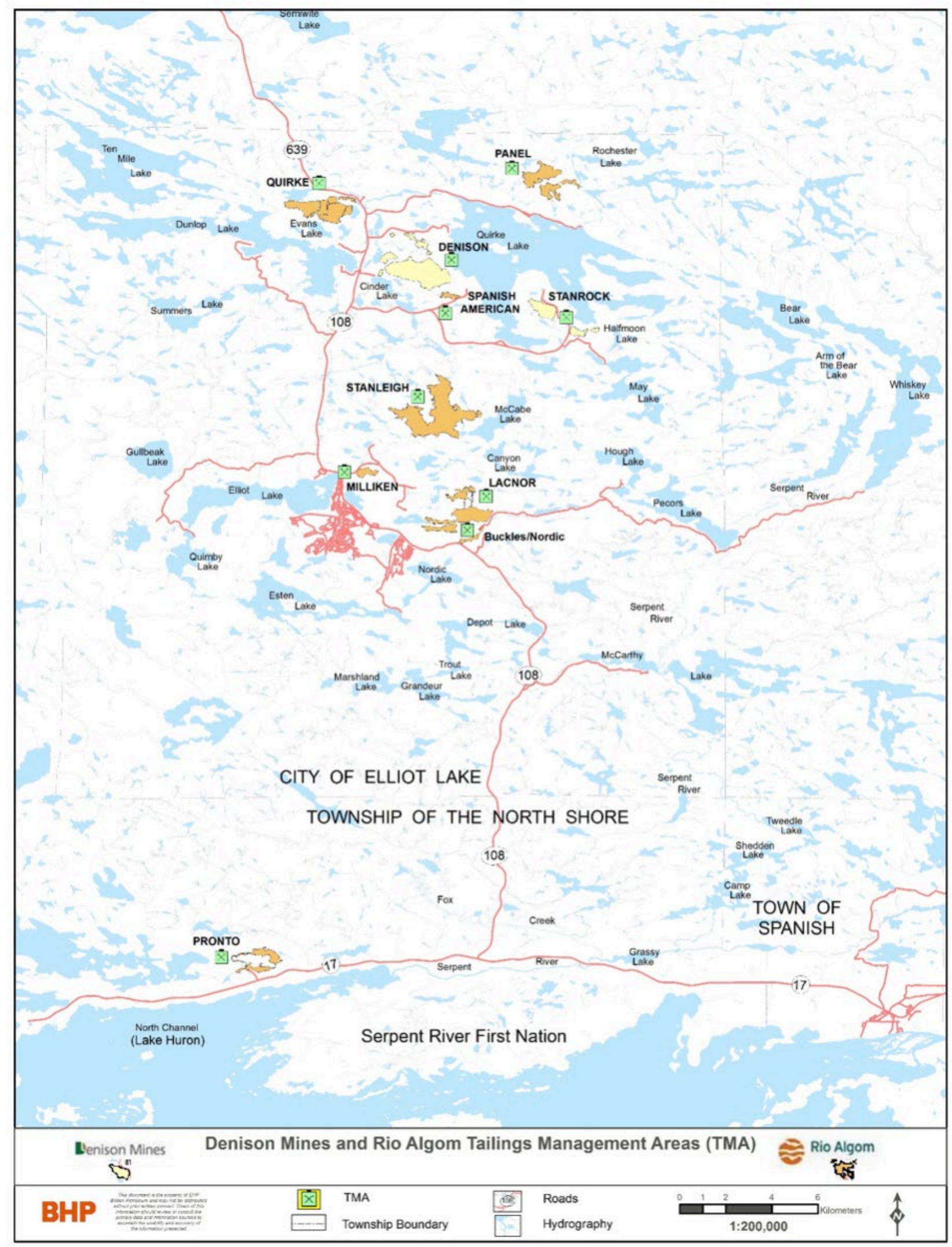

Figure 1 Legacy uranium mining facilities in the Serpent River watershed, Ontario, Canada 


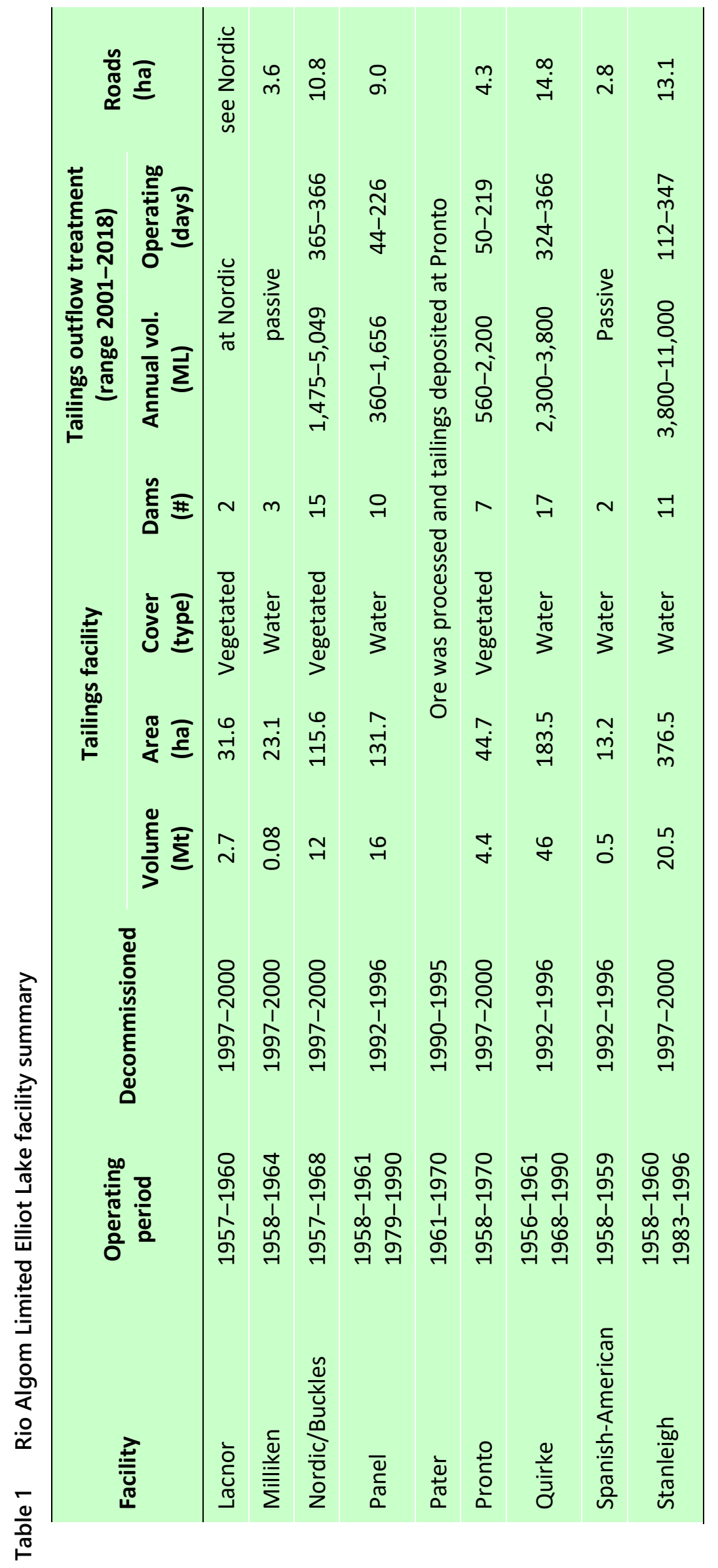


Uranium was extracted from the pyritised quartz conglomerate host rock $(0.1-0.2 \% \mathrm{U})$ using an acid leach process. Although the tailings were neutralised prior to deposition in adjacent low-lying areas, exposed beaches with $5-7 \%$ pyrite resulted in release of acidic and radium-226 drainage water from the tailings facilities until lime and barium chloride treatment was initiated in the early 1970s (James F MacLaren Ltd. 1977).

The construction and operating history of the Elliot Lake sites resulted in tailings facilities with widely varying footprints, tailings inventories and geographical settings (Table 1). Table 2 identifies key closure criteria and objectives that informed closure planning and compares them to current expectations. The robust original design criteria and objectives have enabled the facilities to meet current expectations through supplemental investigations and studies, but without significant physical modifications to the facilities.

Table 2 Rio Algom Limited closure design criteria

\begin{tabular}{|c|c|c|}
\hline Area & Criteria at closure $^{a}$ & Current criteria \\
\hline $\begin{array}{l}\text { Perimeter dam } \\
\text { stability }\end{array}$ & $\begin{array}{l}\text { Static Factor of Safety of } 1.5 \text {. } \\
\text { Dynamically stable for } 1 \text {-in-1,000 year } \\
\text { earthquake. }\end{array}$ & $\begin{array}{l}\text { Meet Canadian Dam Association Dam Safety } \\
\text { Guidelines (CDSG) based on consequence } \\
\text { classification of containment structure (1996). }\end{array}$ \\
\hline \multirow{2}{*}{$\begin{array}{l}\text { Hydraulic } \\
\text { design }\end{array}$} & $\begin{array}{l}\text { Provide adequate water storage to } \\
\text { prevent loss of water cover. }\end{array}$ & $\begin{array}{l}\text { Provide adequate water storage to prevent } \\
\text { loss of water cover. }\end{array}$ \\
\hline & $\begin{array}{l}\text { Design all spillways to pass probable } \\
\text { maximum flood. }\end{array}$ & $\begin{array}{l}\text { Meet (CDSG) based on consequence } \\
\text { classification of containment structure. }\end{array}$ \\
\hline \multirow{2}{*}{$\begin{array}{l}\text { Effluent } \\
\text { discharges }\end{array}$} & $\begin{array}{l}\text { Meet site-specific radium-226 loading } \\
\text { criteria as per Environmental Impact }\end{array}$ & $\begin{array}{l}\text { Regulatory request to establish site-specific } \\
\text { radium-226 discharge objectives. }\end{array}$ \\
\hline & $\begin{array}{l}\text { Statement. } \\
\text { Meet provincial surface water quality } \\
\text { objectives in receiving waters. }\end{array}$ & $\begin{array}{l}\text { Receiving waters assessed against most recent } \\
\text { scientific criteria or reference where reference } \\
\text { is higher. }\end{array}$ \\
\hline \multirow[t]{2}{*}{ Dose limits } & $\begin{array}{l}\text { Worker dose limit of } 50,000 \mu S v \text { p.a. } \\
\text { Public dose limit 5,000 } \mu \text { Sv p.a. } \\
\text { Objective of }<50 \mu \text { Sv p.a. per facility }\end{array}$ & $\begin{array}{l}\text { Worker dose limit of 5,000 } \mu \text { Sv p.a. } \\
\text { Public dose limit 1,000 } \mu \text { Sv p.a.; and } \\
\text { assessment against Health Canada guideline } \\
\text { of }<300 \mu \text { Sv p.a. }\end{array}$ \\
\hline & $\begin{array}{l}\text { Keep environmental impacts and } \\
\text { doses to receptors as low as } \\
\text { reasonably achievable (ALARA). }\end{array}$ & $\begin{array}{l}\text { Objective of }<50 \mu S v \text { p.a. per facility. } \\
\text { Keep environmental impacts and doses to } \\
\text { receptors (ALARA). }\end{array}$ \\
\hline Land use & $\begin{array}{l}\text { Allow a productive land use or } \\
\text { acceptable alternative. }\end{array}$ & $\begin{array}{l}\text { Allow a productive land use or acceptable } \\
\text { alternative. }\end{array}$ \\
\hline
\end{tabular}

a Amalgamated from Environmental Impact Statements (RAL 1995, 1997; CNSC 2002)

Closure planning included cost-benefit analysis and optimisation between water covers and vegetative covers with various degrees of in-basin relocation. Closure decisions at operating and legacy facilities were supported by geotechnical, hydrological and hydrogeological assessments of each facility including probabilistic assessment of failure modes incorporating climate change and site-specific seismic assessments (Golder 1992a, 1992b, 1996, 1999). As all tailings facilities rely on engineered centre-lined earth dams for long-term containment of tailings, closure planning also included consolidated as-built dam instrumentation, maintenance and inspections programs for each facility. Annual dam safety inspections were initiated in 1994 with dam safety reviews initiated at Quirke in 1999 (Morgenstern \& MacPhie 1999) and performed in conformance with Canadian Dam Association guidance at all facilities in 2006 (SNC), 2013 (Klohn Crippen Berger (KCB)) and scheduled for 2019. 
Environmental assessments included source term, environmental pathway and cumulative effects modelling throughout the Serpent River watershed (Specialists in Energy, Nuclear and Environmental Sciences (SENES) 1992, 1996; CNSC 2002). Closure environmental baseline assessments throughout the watershed were completed in 1994 (SENES \& Niblett Environmental Associates Inc. 1994) and 1999 (Minnow \& Beak 2001). These closure baseline studies were supplemented by assessments of radionuclide-associated risk to any biota accessing and feeding within the tailings facilities (Minnow Environmental Inc. (Minnow) 2007) and design of objectives-driven, statistically-based source term monitoring programs to track changes in releases from the sites and loadings to the watershed (Minnow 2002). Watershed environmental effects monitoring and supporting source term monitoring design are revised and subject to regulatory approval once every five years with integrated 'State of the Environment' reports issued in 2008, 2011, 2015 (Minnow 2008, 2011, 2017) with next watershed field program scheduled for the fall of 2019.

\section{Water management and dam surveillance}

Annual precipitation in the Elliot Lake area is $954 \mathrm{~mm}$ with $183 \mathrm{~mm}$ as snow fall (Golder 2017). Water management infrastructure includes 68 containment dams, $>20 \mathrm{~km}$ of diversion and conveyance channels, 28 spillways, eight stoplog structures, six weirs, five control valve locations, an intake siphon and two pump stations. With the exception of the two seepage interception pump houses, water management infrastructure is designed for passive conveyance (spillways and channels) or mechanical control (stop log structures, siphons, and water control valves). Active water management is limited to operation of the two pump houses, five treatment plant influent valves and discharge stop log structures, one water intake valve and one inter-basin stop log structure. Treatment plant influent valves and pump station pumps and associated flows are controlled through programable logic controllers connected to a central Supervisory Control and Data Acquisition (SCADA) network incorporating alert levels and dial-out alarms. Given the direct linkages between hydraulic capacities of the facilities and dam safety, water management and dam surveillance programs have been integrated for post-closure care and maintenance.

Following closure construction and establishment of final basin configurations, the network of approximately 244 dam instruments (i.e. piezometers) have been installed and monitored semi-annually with out-of-range results triggering Engineer of Record notification and follow-up monitoring. All results are reviewed annually by the Engineer of Record as part of the annual dam safety inspection. Two follow-up dam instrumentation reviews have resulted in minor modifications and addition of alert levels to the piezometer monitoring program and addition of settlement plates at two locations.

Routine maintenance efforts focus on removing woody vegetation over $1 \mathrm{~m}$ in height from the 68 containment structures and brushing the $100 \mathrm{~km}$ internal road network. Road maintenance efforts have been focused through maintenance standards established based on road classification (primary, seasonal, $4 \times 4$ ). Routine maintenance also includes inspection and clearing of the 127 culverts associated with the facility. Periodic maintenance activities in the post-closure period for specific domains have included culvert replacements, restoration of internal dyke design elevations, replacement of settling pond drop box structures with a spillway, reinstatement of diversion channels, and restoration of design elevation of lowhead operating earthen spillways.

\subsection{Inspection and monitoring response}

Over the 18-year post-closure operating period (2001-2018), water basins associated with the facilities have generally operated within designated elevation ranges. Periods of operations outside of designated operating ranges (but within allowable freeboard) have been associated with planned maintenance or one of the three inspection response maintenance events. As an example, Figure 2 shows elevation monitoring at the Quirke facility, modifications to operating elevations to reflect live storage improvements and drawdown for maintenance activities. 


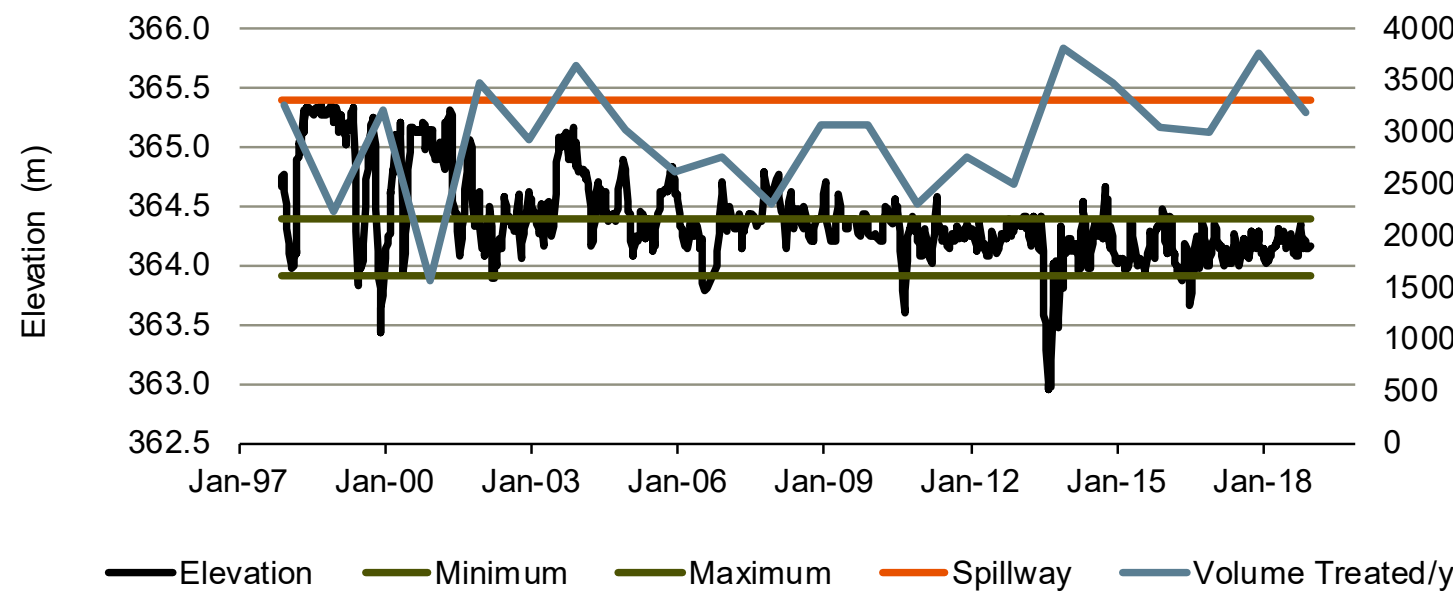

1999 Permanent spillway installation Cell 18 drawdown 2000 Y2K preparation Cell 18 drawdown

2006 Cell 18 drawdown for influent culvert replacement

2011 Cell 18 drawdown for cell lime addition water supply line installation

2013 Cell 18 drawdown for Dam D maintenance

\section{Figure 2 Quirke Cell 18 operating elevation monitoring}

Responses to semi-annual dam instrumentation monitoring have been limited to Engineer of Record reviews, verification sampling and well maintenance.

Inspection response in the post-closure period have included three unplanned maintenance events. Two of the three inspection response events were initiated via audio triggers as the toe of the structures were submerged and seepage was not visible. The third inspection response event was detected by observations of increased seepage resulting from separation of concrete slabs of the overflow spillway. These events have reinforced the importance of geotechnical inspection personnel familiar with the facility and observant of multiple lines of evidence to detect change. All response programs included interim control of upstream ponds, supplemental monitoring to confirm no environmental impact, rehabilitation design by the Engineer of Record and required regulatory notifications and approvals.

\subsection{Post-closure tailings facility modifications}

Across the eight tailings facilities the key post-closure hydraulic facility modifications have been limited to modifications of the Quirke and Panel overflow spillways and operating elevations to improve live storage in response to continued treatment and application of seepage barriers to reduce seepage through Dykes 14 and 15 at the Quirke facility.

Requirements for increased live storage capacity at Quirke and Panel were required to adapt to community and regulatory changes in treatment expectations post-closure. Environmental impact assessment and closure planning at the Quirke and Panel facilities were based on discontinuation of treatment once post-closure radium-226 loading criteria were achieved. Post-closure new federal radium discharge criteria were established at concentrations above those projected in environmental assessments. This combined with community diversification foci of recreational and retirement development, necessitated extending treatment periods (Section 3.1) and associated follow-on requirements to improve live storage as reflected in decreasing operating elevations in Figure 2.

Post-closure remediation and impact evaluation of higher than expected subsurface flows at the Quirke facility have been addressed through application of a seepage barrier in Cell 14 and assessment of potential acid loadings from Cell 15 during drought conditions.

The Quirke tailings facility (Figure 3 ) is a tiered structure with a $14 \mathrm{~m}$ elevation drop from west to east. The internal dykes are 5 to $9 \mathrm{~m}$ high engineered clay core structures founded on tailings. Freshwater is taken 
seasonally from Gravel Pit Lake to maintain the water cover in the upgradient Cells 14 and 15. Construction and early performance monitoring indicated that subsurface flow below Dykes 14 and 15 was above design (Golder 1994, 1997) and till cutoff trenches were installed at known cross-dyke locations of Dyke 15 and about $100 \mathrm{~m}$ of Dyke 14 near the north abutment was sealed with a till berm in 1997. In 2003 Cell 14 was drained and a $0.3 \mathrm{~m}$ thick till blanket was placed upstream of Dyke 14 and approximately $68 \%$ of the cell was covered with a silty sand diffusion barrier (Golder 2011).

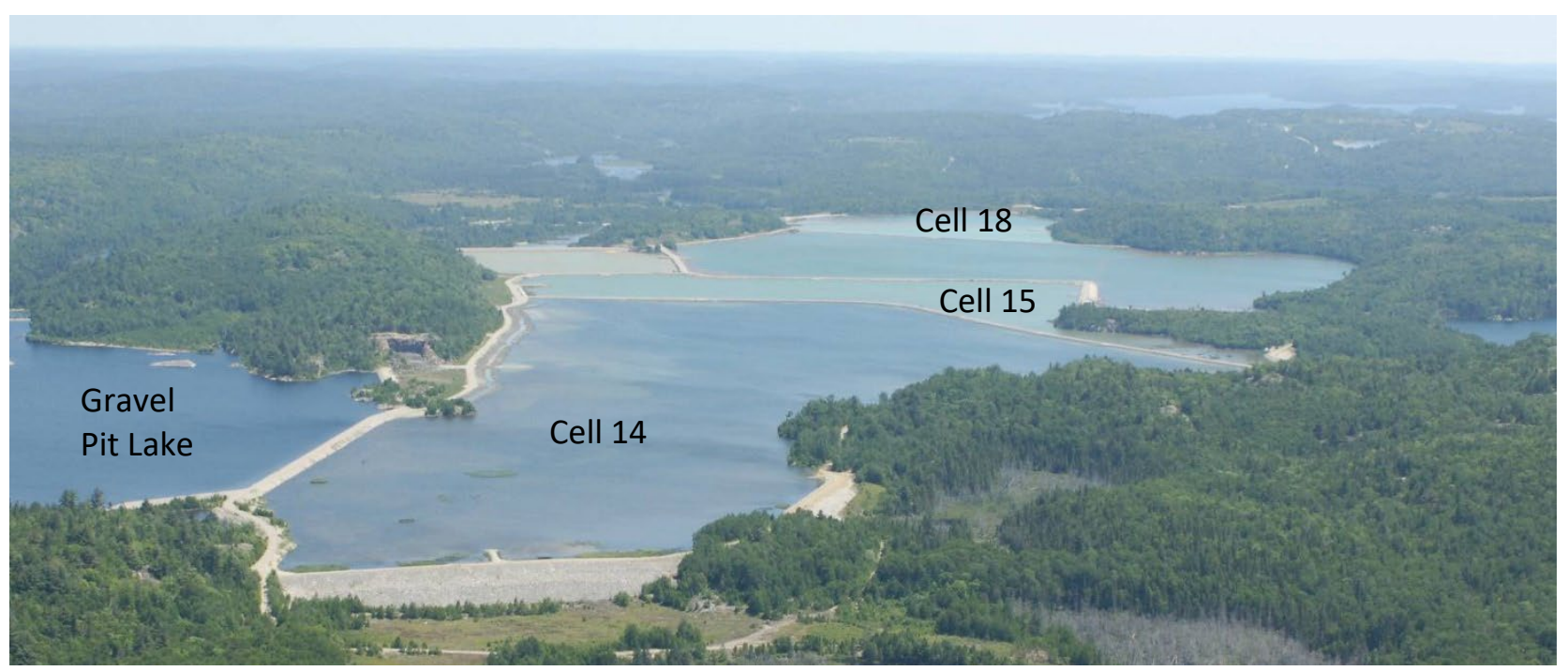

Figure 3 Quirke tailings facility

Post remediation subsurface water losses remain in the 35 to $40 \mathrm{~L} / \mathrm{s}$ range and in drought years elevations in Cell 15 have been as much as $1 \mathrm{~m}$ below spillway elevation, exposing tailings beaches along the toe of Dyke 14. In 2010 RAL retained EcoMetrix Incorporated (2011) to estimate potential acidity loads from the periodically exposed tailings using bathymetry of Cell 15 and measured soluble acidities in potentially exposed tailings. As the projected incremental annual lime demand is $1 \%$ to $3 \%$ of the total annual facility lime consumption and treatment of historic acid products in porewater water is expected to continue for over 30 years, no further remedial measures are planned at this time. Seepage rates, development of vegetation and water balance monitoring, including climate change impacts, will continue to be monitored and evaluated during scheduled periodic reviews to better inform long-term alternatives if required.

\subsection{Dam safety reviews}

Dam safety reviews conducted in 2006 (SNC) and 2013 (KCB) indicated that the design criteria and design events (earthquakes and floods) established during closure planning continued to meet Canadian Dam Association (CDA) guidelines based on the consequence classification of the containment structures and the generally accepted geotechnical approaches of the day. In keeping with changes in knowledge and best practice, work undertaken since the 2013 dam safety review include climate change assessments (Golder $2017,2018)$, advanced liquefaction assessment and updates to dam break analysis to incorporate tailings run-out. These additional studies informed the emergency response planning including community workshops. These continuous improvement initiatives will be assessed against current best practice as part of the 2019 dam safety review.

\section{Water quality and treatment}

The key constituents of concern requiring collection and treatment of contact waters from the Elliot Lake pyritic uranium ore tailings are acid, iron and radium-226. Where natural topography supported containment in bedrock basins, water covers are used as the primary control for acid generation and barium chloride is used at the treatment facilities (Stanleigh and Panel) to control radium-226 releases. Where original deposition and natural topography did not favour construction of low permeability structures, pyrite 
oxidation is proceeding to the depth of the watertable with surface and groundwater collected and treated with lime for acid control and iron removal (Pronto and Nordic). At the tiered Quirke facility declining acidic levels, sulphate and iron concentrations indicate water covers have been effective in controlling new acid generation, but the hydraulic gradient across the basin is pushing historic acidic porewaters into downgradient cells requiring both lime and barium chloride to treat acid and remove radium- 226 .

\subsection{Water covers}

Water covers in the uni-level Panel and Stanleigh flooded basins have been highly effective in controlling acid generation and water upstream of treatment is better than water quality criteria established to protect aquatic life (Minnow 2017). Although radium-226 concentrations remain below aquatic life criteria, they remain above federal discharge criteria of $0.37 \mathrm{~Bq} / \mathrm{L}$ requiring surface waters to be treated prior to release to downstream environments. Following flooding and in situ liming of the basins, $\mathrm{pH}$ in both basins has remained in the 6.3 to 7.7 range and radium-226 and sulphate are approaching concentrations predicted for 50 years post-closure (Figure 4 ).

\section{Panel Treatment Plant Influent}
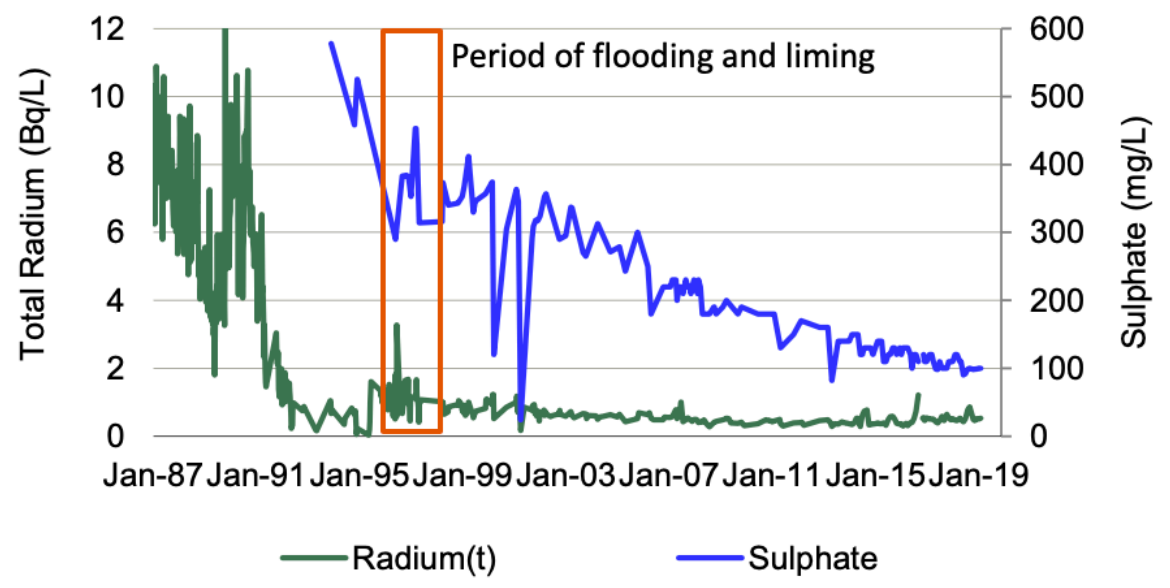

\section{Stanleigh Treatment Plant Influent}

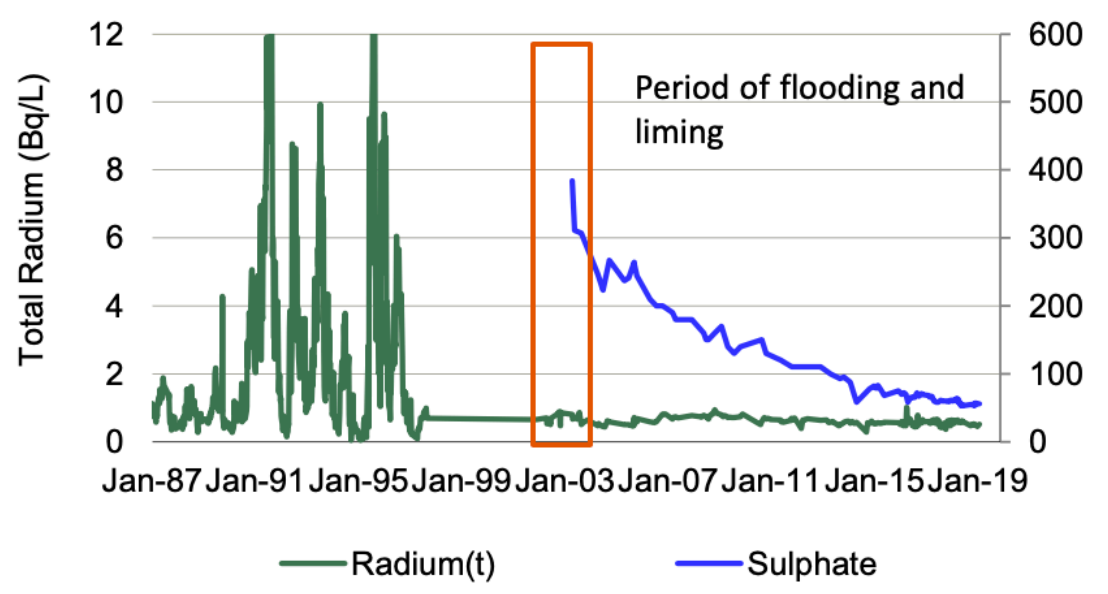

Figure 4 Radium-226 and sulphate concentrations at Panel and Stanleigh flooded basins

Improving influent water quality has resulted in decreasing efficiency of radium-226 removal in the treatment process. Transitory periods of refractory radium-226 were first observed at the Stanleigh facility in 2008 and were initially controlled through-flow reductions and plant shutdowns during refractory periods (generally 
one to two weeks in Spring and Fall) and augmented by silt curtain installations. While initial source term and alternate treatment investigations (ferric sulphate and floc addition) indicated small particle size was preventing settling, the intermittent nature of the refractory period combined with low mass of target removal rates ( $<10 \mathrm{pg}$ radium-226/L influent) delayed identification of causative agent and development of an effective treatment strategy. Full-scale trials of ex-situ pre-formed barite (XSB) in March/April 2018 demonstrated effective radium-226 removal by XSB, but performance during a period of refractory radium-226 needs to be verified during the next refractory period. Detailed design and permitting of plant modifications to implement permanent XSB process is in progress and scheduled for implementation in 2019. Investigations into the causative agents and indicators of refractory radium-226 will continue in 2020 and will complement ongoing work on the geochemical controls of radium-226 release in the basins and identification of conditions under which radium-226 release could change in the future.

\subsection{Vegetated covers}

Cover design criteria for the Elliot Lake vegetated facilities were (i) to establish sustainable vegetation to prevent exposure and air-born release of tailings; and (ii) keep gamma doses to casual recreational users below $50 \mathrm{mSv} / \mathrm{a}$ assuming a 200 hour per annum exposure (hiking). Sustainable vegetation was established as early as the late 1970 s at most facilities through surface neutralisation, fertilisation and direct vegetation. During closure, low-lying areas subject to upward salt migration and vegetative die-back were rehabilitated through application of simple capillary barrier and till covers. At the Pronto facility, 20.9 ha of saturated fine tailings were covered with a $40 \mathrm{~cm}$ thick cover of loose non-dioxin paper mill solids over the course of three winters (1999-2002). The cover has been effective in sustaining vegetation (Figure 5).

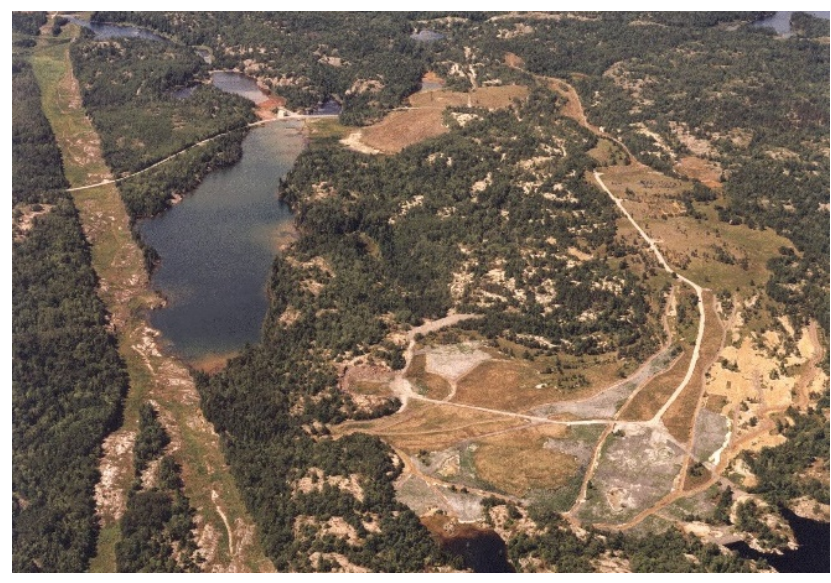

(a)

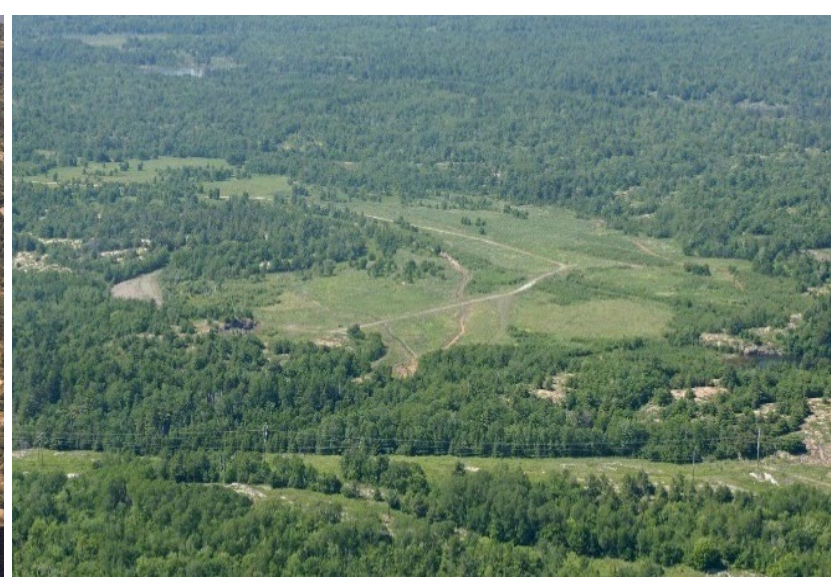

(b)

Figure 5 Pronto biosolids application to support sustainable vegetation: (a) 2001 during application; (b) 2005 post-application

Evaluation of influent monitoring data for the period 2003-2014 shows statistically significant decreases in influent acidity and decreasing trends for sulphate (Minnow 2017) in both the Nordic (N-17) and Pronto influents (PR-02). This is reflected in reduced lime consumptions rates at the Pronto facility, but not at the Nordic facility where influent iron concentrations remain an order of magnitude above those at Pronto (Figure 6). 


\section{Nordic Treated Volume and Lime Consumption}

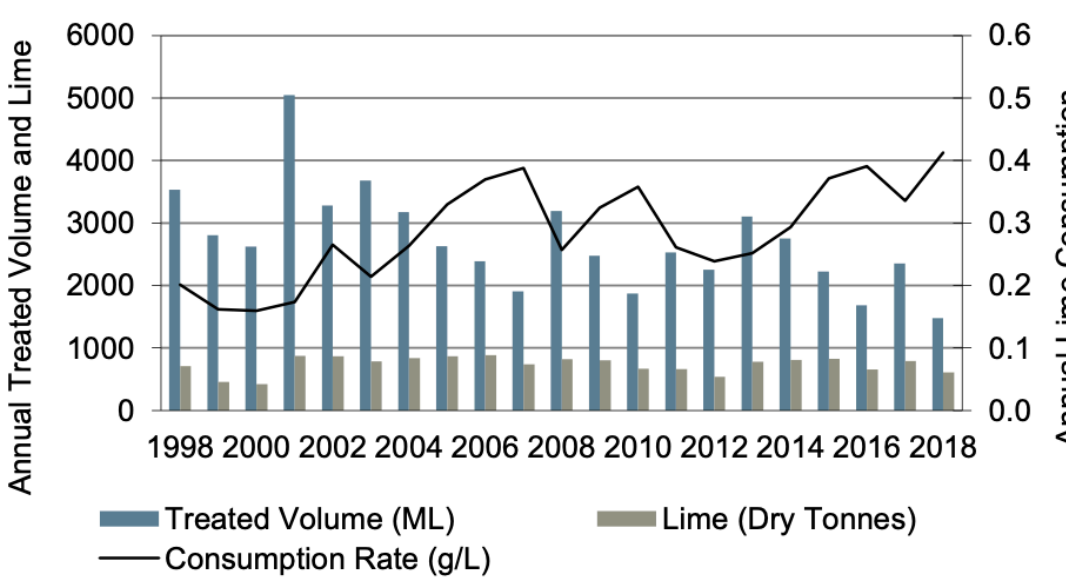

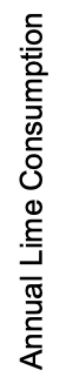

\section{Pronto Treated Volume and Lime Consumption}

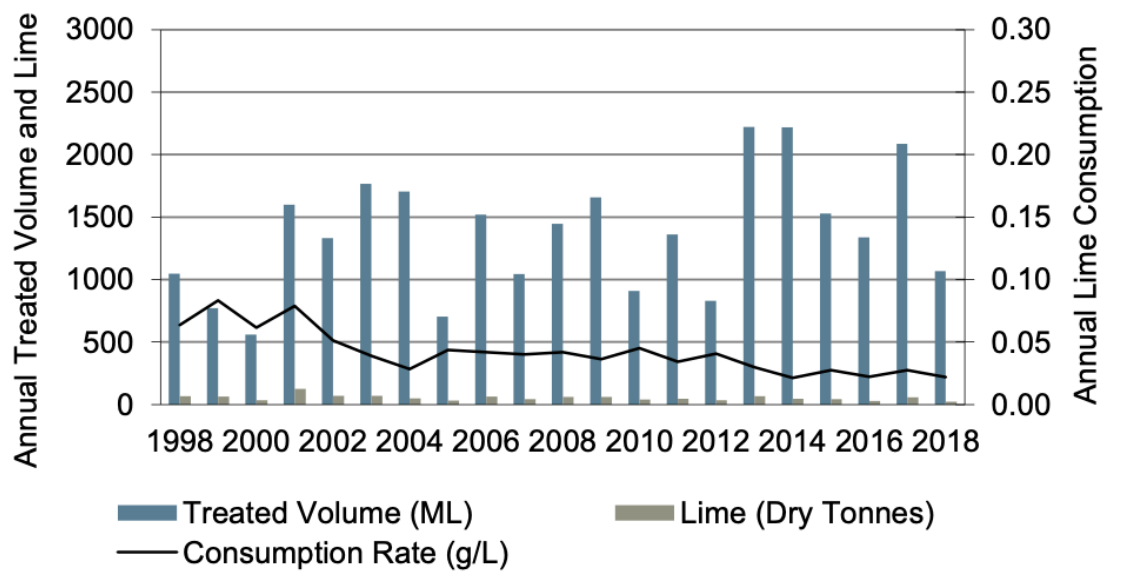

Figure 6 Post-closure lime consumption at the Nordic and Pronto treatment facilities

\subsection{Operation and maintenance}

All five treatment plants are instrumented for reagent addition and flow control as well as reagent consumption, $\mathrm{pH}$ and building condition (power, communications, temperature and fire) monitoring. Programable logic controllers (PLC) communicate with a central Supervisory Control and Data Acquisition (SCADA) with controlled access via designated mobile devices. Alert levels and notification alarms as well as critical alarms that automatically shutdown operations are incorporated in network programming. An on-call operator is available 24 hours a day to respond to alarm notifications sent via cell phone. The remote monitoring network has been in place since 1997 with PLC replacement and SCADA upgrades completed in 2016-2017.

Treatment facilities are visited on workdays when operating and weekly when shutdown. Operator duties during visits include inspecting and recording condition of critical equipment (tank elevations, pump speeds), conducting grab sampling and quality control checks of $\mathrm{pH}$ control probes and making operating adjustments to flow rates and reagent addition as per operating conditions and operational monitoring results. Target operating levels, alert levels and response plans are documented in facility operating manuals with on-screen notifications programmed into the data validation program of the performance monitoring database.

Routine maintenance activities include scheduled equipment maintenance as per manufacturer's recommendations, testing of critical alarms, mixing of reagents and general housekeeping. Planned maintenance includes cleaning of reagent tanks, replacement of reagent addition lines and scheduled preventive maintenance of reagent pumps, agitators and influent valves. Electronic maintenance records are maintained for critical equipment. 
Three of the treatment plants not modified during closure execution have been upgraded post-closure. The 1981 Stanleigh sand filtration treatment plant was replaced with a conventional lime and barium chloride treatment plant with downstream settling pond in 2007. Post-flooding loadings to the treatment plant were reduced substantially and downsizing of the facility enabled the plant to be taken off-grid with power supplied by a cross-flow turbine in the influent siphon. The 1977-1978 vintage Panel and Quirke treatment facilities were upgraded in 2010 and 2016 respectively. Both buildings were inspected and found to be structurally sound and treatment was still effective so there were no significant modifications to process flows or major equipment. Rather upgrades focused on improvements in electrical systems, secondary containment, insulation and equipment platforms to improve safety and maintenance access.

\section{$4 \quad$ Watershed}

Environmental effects monitoring programs were completed throughout the watershed in 1994 (SENES \& Niblett Environmental Associates Inc. 1994) and 1999 (Minnow \& Beak 2001) to establish pre-closure conditions. The original design document (Beak International Incorporated (Beak) 1999) included water quality, sediment quality, benthic invertebrates and fisheries assessments and extended from head waters of the watershed (Ten Mile Lake) to the Serpent River Harbour and into Lake Huron (Figure 1). The 1999 program included multiple lake, depositional stream and erosional stream reference areas and was designed to assess the recovery of the receiving environment following closure implementation. Program design also included assessment criteria and triggers for modifying the scope (parameters, frequency, elements) and spatial extent of the program in response to watershed recovery and performance as well as monitoring and response plans for non-favourable changes. Water quality monitoring is continuous and augmented by environmental effects monitoring at five-year intervals $(2004,2009,2014,2019)$ with regulatory approval of study design preceding each field program.

Water quality throughout the watershed has improved significantly since 1999 . With few exceptions, water quality at potentially mine-impacted lakes is better than program benchmarks for the protection of aquatic life. Robust data quality protocols and statistical evaluation of validated datasets have been applied to focus ongoing water quality monitoring on the seven mine indicator substances (barium, iron, manganese, $\mathrm{pH}$, radium-226, sulphate and uranium) and associated hardness. Sulphate and radium-226 concentrations downstream of the tailings facilities were close to, or better than, 1999 cumulative predictions and with statistically declining trends are on track to achieve 2099 environmental impact assessment predictions (Table 3).

Table 3 Concentration predictions at Serpent River Watershed stations compared to 2018 values

\begin{tabular}{|c|c|c|c|c|c|}
\hline Location & Predicted versus measured & Year & $\begin{array}{c}\text { Sulphate } \\
\text { (mg/L) }\end{array}$ & $\begin{array}{c}\text { Radium-226 } \\
\text { (Bq/L) }\end{array}$ & $\begin{array}{l}\text { Uranium }^{\mathrm{a}} \\
(\mathrm{mg} / \mathrm{L})\end{array}$ \\
\hline \multirow{3}{*}{ Quirke Lake } & Cumulative prediction $^{\mathrm{b}}$ & 1999 & 173 & 0.067 & none \\
\hline & Annual average & 2018 & 29 & 0.017 & 0.0011 \\
\hline & Cumulative prediction ${ }^{\mathrm{b}}$ & 2099 & 23 & 0.042 & none \\
\hline \multirow{3}{*}{ McCabe Lake } & Cumulative prediction $^{c}$ & 2012 & 32 & 0.100 & 0.0029 \\
\hline & Annual average & 2018 & 30 & 0.100 & 0.0006 \\
\hline & Cumulative prediction ${ }^{b}$ & 2099 & 11 & 0.026 & none \\
\hline \multirow{3}{*}{ Nordic Lake } & 2012 prediction $^{c}$ & 1999 & 260 & 0.067 & none \\
\hline & Annual average & 2018 & 138 & 0.028 & 0.0007 \\
\hline & Cumulative prediction ${ }^{\mathrm{b}}$ & 2099 & 127 & 0.063 & none \\
\hline
\end{tabular}

a Predicted uranium values converted from Bq/L to $\mathrm{mg} / \mathrm{L}$. ${ }^{\mathrm{b}}$ Predicted values for 1999 and 2099 based on cumulative effects assessment (CNSC 2002). ' Predicted values for 2012 represents 2005 year presented in RAL (1997) due to delays in construction and flooding of the Stanleigh facility. 
While water quality has improved significantly post-closure, sediment concentrations have shown little change and are generally elevated downstream of the mines. However, sediment toxicity testing in 2009 showed no difference in growth or survival of the benthic invertebrate Chironomus dilutes between reference and mine exposed lakes (Minnow 2017).

To further examine sediment recovery, sediment deposition studies were conducted in three near-field lakes (Nordic, Quirke and McCabe) between 2011 and 2012 using both sediment traps and core profiling. Deposition rates in the three lakes ranged from 0.3 to $0.74 \mathrm{~mm}$ p.a. (Minnow 2013). Therefore, even at the lake with highest deposition rates it would take more than 10 years to accumulate the $1 \mathrm{~cm}$ of sediment used to monitor sediment change in the program. Based on the results of the sediment deposition study, the frequency of sediment and benthic invertebrates was reduced to every 10 years in the 2014 design (Minnow 2016) with the next monitoring scheduled to occur in 2019.

Benthic invertebrate communities downstream of the mines have shown some improvement since 1999. Across five metrics (density, number of taxa, correspondence analysis axes 1, 2 and 3 ) the total number of metrics for which exposure lakes differed from reference declined from four in 1999 to two in 2009. This supports a hypothesis of gradual recovery since 1999 in exposure lakes, but indicates that deviations from reference persist in both the density and community structure of exposure lakes as of 2009 (Minnow 2011).

Fish health assessments conducted in seven downstream lakes in 1999 indicated no difference between fish health between mine exposed and reference lakes, although reduced abundance was observed in McCabe Lake. Only McCabe Lake was carried forward into Cycle 2 as benthic invertebrate community evaluations provide a more robust indicator of watershed recovery.

Incremental dose estimates for critical ecological and human health receptors were updated in 2004 and 2009 using watershed monitoring data. A special investigation was undertaken in 2009 to inform pathway assumptions on secular equilibrium, contributions of the thorium-232 decay chain to sediment exposures and update bioaccumulation factors. A survey of fish and wildlife consumption by Serpent River First Nation (SRFN) fishers and hunters and their families (SRFN 2010) provided community-specific values for fish and wildlife intake rates and consumption from area rates.

The 2009 calculated doses to aquatic biota and riparian wildlife in the six near-field lakes (Quirke, McCabe, May, Nordic, Elliot, McCarthy) were less than the United Nations Scientific Committee on Effects of Atomic Radiation (UNSCEAR 1996) benchmarks of 10 and $1 \mathrm{mGy} / \mathrm{d}$ respectively. The upper limit of incremental dose to theoretical critical receptor drinking water and consuming fish and game from the lake ranged from $0.023 \mathrm{mSv}$ p.a. at McCarthy Lake to $0.103 \mathrm{mSV}$ p.a. at May Lake which are well below public does limit of $1 \mathrm{mSV}$ p.a. and Health Canada guideline of $0.3 \mathrm{mSv}$ p.a. (Minnow 2017). The calculated incremental dose to members of the Serpent River First Nation was 0.05 mSv p.a.

The 2009 public dose estimates were based on demonstrating that even the upper bounds of exposure of critical residents remained below public dose limits. In 2017 a representative incremental public dose of $0.012 \mathrm{mSV}$ p.a. was derived for a typical resident of Elliot Lake (EcoMetrix Incorporated 2016). The dose was calculated based on radon and gamma surveys of public walking trails crossing Rio Algom Limited property, analysis of radionuclides in drinking water and a public survey to determine amount of time residents spend hiking on the mining properties and level of consumption of fish from local lakes.

The design for the 2019 environmental effects monitoring and five-year reviews of radiological dose and performance monitoring is in progress. Key elements in the fifth design cycle will include design for updates of hydrogeological models for each tailings facilities and development of region-specific radium-226 benchmarks to be used in performance evaluations.

\section{Conclusion}

The construction and operating history of the Elliot Lake sites resulted in tailings facilities with widely varying footprints, tailings inventories and geographical settings. Through the application of robust original design criteria, objectives and cost-benefit methodology, closure plans were developed and implemented that have 
generally met performance expectations and have required only modest post-closure facility modifications. Routine operations, care and maintenance metrics are generally stable and predictable with continuous improvement driven by investigations to evaluate performance relative to evolving knowledge and understanding and improvements in technology. Focus on our core business of responsible management of our sites has enabled surrounding communities to successfully transition from mining to retirement and recreational property-based economies.

\section{Acknowledgement}

Thanks to Art Coggan, Shiu Kam, Randy Knapp, Roger Payne and Cynthia Russel who dedicated decades of their careers to the success of the Elliot Lake mine closure.

\section{References}

Beak International Incorporated (Beak) 1999, Serpent River Watershed Monitoring Program Framework Document, Brampton.

Canadian Environmental Assessment Agency (CEAA) 1996, Decommissioning of Uranium Mine Tailings Management Areas in the Elliot Lake Area, report of the Environmental Assessment Panel, Ottawa.

Canadian Nuclear Safety Commission (CNSC) 2002, Environmental Assessment Screening Report Possession and Management of Waste Nuclear Substances at Spanish American, Milliken, Lacnor, Nordic/Bucles, and Pronto Historical Properties in the Elliot Lake Area, Ontario, Ottawa.

EcoMetrix Incorporated 2011, Acidity Release Controls at Quirke Cell 15, Mississauga.

EcoMetrix Incorporated 2016, Interim Public Dose Estimation for the Closed Mines of the Serpent River Watershed, Mississauga.

Golder Associates Ltd. (Golder) 1992a, Probabilistic Assessment of the Long-term Performance of the Quirke Mine Waste Management Area, Toronto.

Golder 1992b, Probabilistic Assessment of the Long-term Performance of the Panel Mine Waste Management Area, Toronto.

Golder 1994, Interim Assessment of the Hydrogeological Performance of Cell No. 14, Quirke Mine Waste Management Area, Toronto.

Golder 1996, Geotechnical Aspects of Decommissioning and Simplified Risk Assessment Stanleigh Mine Waste Management Area, Toronto.

Golder 1997, Summary of Water Budget Analyses, Toronto.

Golder 1999, Probabilistic Assessment of the Long-term Performance of Lacnor, Nordic, Pronto and Spanish-American Waste Management Areas Elliot Lake, Ontario, Toronto.

Golder 2011, Quirke TMA Cell 15 Water Balance, Toronto.

Golder 2017, Climate Baseline Assessment Rio Algom Limited Tailings Management Areas Around Elliot Lake, Toronto.

Golder 2018, Climate Change Projections for Elliot Lake Tailings Management Areas, Toronto.

James F MacLaren Ltd. 1977, Environmental Assessment of the Proposed Elliot Lake Uranium Mines Expansion Volume 1 Background Information.

Minnow Environmental Inc. (Minnow) and Beak 2001, Serpent River Watershed Monitoring Program - 1999 Study Final Report, Georgetown.

Minnow 2002, Overview of Elliot Lake Monitoring Programs and Source Area Monitoring Program Design, Georgetown.

Minnow 2007, Serpent River In-Basin Monitoring Program: Cycle 2 Interpretive Report Revision 1, Georgetown.

Minnow 2008, Serpent River Watershed State of the Environment, Georgetown.

Minnow 2011, Serpent River Watershed State of the Environment Report, Georgetown.

Minnow 2013, Determination of Deposition Rates Using Sediment Core Profiling and Sediment Traps in McCabe, Quirke and Nordic Lakes, Elliot Lake, Ontario, Georgetown.

Minnow 2016, Cycle 4 Study Design for the SRWMP, SAMP and TOMP, Georgetown.

Minnow 2017, Serpent River Watershed Cycle 4 (2010 to 2014) State of the Environment Report, Georgetown.

Morgenstern, NR \& MacPhie HL, 1999, External Review Report Quirke Waste Management Area Tailings Safety Review, Elliot Lake, Ontario.

Rio Algom Limited (RAL) 1995, Decommissioning of the Quirke and Panel Waste Management Areas.

RAL 1997, Comprehensive Study Report Decommissioning of the Stanleigh Waste Management Area, Mine and Mill.

SENES Consultants Limited (SENES) 1992, Supporting Document // Environmental Pathways Analyses for the Quirke and Panel Decommissioning Proposals, Richmond Hill.

SENES 1996, Supporting Document IV Environmental and Pathways Analyses for the Stanleigh Mine Decommissioning Project, Richmond Hill.

SENES \& Niblett Environmental Associates Inc. 1994, Evaluation of the Aquatic Environment in the Serpent River Watershed. Serpent River First Nation (SRFN) 2010, Fish and Waterfowl Consumption Study.

United Nations Scientific Committee on the Effects of Atomic Radiation (UNSCEAR) 1996, Report to the General Assembly, with Scientific Annex, United Nations, New York. 
